\title{
Research on Formalism and New Criticism of Dickens' Novels
}

\author{
Wang lina \\ lecturer, Zhejiang Yuexiu University of Foreign Languages \\ Zhejiang,China \\ E-mail: wanglina2015hy@163.com
}

\section{Keywords: Dickens; Formalism; Criticism}

\begin{abstract}
English novelist Charles Dickens never went from a few days to learn the poor boy to the world-famous generation writer, through the arduous process. He left a valuable human literary heritage. Dickens and his writings, has been one of the key concerns of the Anglo-American literary critics. This paper intends to investigate pre-war Anglo-American Literary Criticism Dickens studies reveal a variety of different schools of criticism and interpretation of his works; they also discussed the reasons for the position of judge and the formation of the advantages and disadvantages exist, so that both of our Dickens The researchers provide the necessary reference, but also deepen understanding of Dickens its creation.
\end{abstract}

\section{RESEARCH ON FORMALISM OF DICKENS' NOVELS}

Narrative Techniques . "Skills novel" 1921, published in literary criticism set off a firestorm. Percy is author comments that following the Henry James's most important literary aesthetics critic, his "novel technique" is also considered to be "the first monograph of the novel as art." Percy recommend literary criticism should take a more scientific and objective methods. He believes that criticism should not discuss fiction writer living background, new critics should focus on the novel "form, design, construction," Critics method is to "read this."

In the process of reading text, viewing angle is an aspect of great concern to beat the West, in his opinion, the whole complex of fiction writing skills, and perspective is crucial, so choose whether proper perspective will determine success or failure of the novel. In this regard, Percy pointed out, "David Copperfield," as described in the reader browse all the long years of the first-person narrative is not deliberately dramatic, but very natural. Dickens has not brake as neither meddling figure in the novel, like Thackeray, unlike Turgenev as guilty of gushing line drawing problems. Dickens to withdraw a thing, but will all the characters in the past, the environment, the story with a picture collage-like approach together with a calm attitude to remember. Both through first-person narrative vividly clear Copperfield growth process, but also so that the relationship of the novel, the story of each character and the novel is balanced.

In the "novel technique", the Percy creative insight to each check a variety of narrative perspective. He said the novelist as an impartial, or with a personal prejudices spectator, from the outside to describe those characters in the novel; or you can stand on the position of omniscient person, from the character's inner world to portray them; or you can put yourself in the position of one of the characters, and the thoughts and motivations of the other characters pretend to know nothing about the way; or you can take a certain attitude ranged between these attitudes. Percy respected more complex narrative with Dickens in "Bleak House" in the Bian.

"Picture" and "drama" is now often said that people tell and show two narrative way. According to the definition under Percy, "the picture that someone receives event on the screen reflects awareness", and if "the authors take the reader directly visible and audible on the facts before it, let the facts tell the story of their own, this time on the scene accepted the dramatic treatment. "picture can play a supportive role to play in this regard Percy think Dickens is more clever, he pointed out," David Copperfield "and" Bleak House "is a broad picture of laying the groundwork, Then the reader into the romantic drama scene. 
Structure. Percy followers Pelham Edgar, published in 1933 "on the art of fiction from 1700 to the present," and claims the book traces the "structural changes in the history of the English novel." The forward to the style, the idea was shot by the influence of the West. And Percy, like Edgar also stressed the novel form. Dickens and Percy different mild praise, Edgar Dickens did not appreciate, he believes that "in terms of structure, Dickens is his own worst enemy, if he can count on self-criticism, he might be able to become a more outstanding novelist.. "Edgar frank reading their favorite Dickens novel, but do not tolerate the slightest attention to the practice of Dickens novel form and structure. For all the practice Dickens, Edgar could not understand. He believes that a good writer must not at any time to change the character of the hero and the characters in the novel based on the needs of readers. In his opinion, Dickens most concerned about is in any case let his readers to meet, rather than the form and structure of the novel.

Novelist, critic Edwin Muir in the "structure of the novel," also discusses at some length with a Dickens novel. "Structure of the novel" is also a popular Henry James, love. Mount Foster, Percy affect aesthetic theory works. In the discussion, Samuel Dickens novel basic structure negative attitude that only good shape Dickens memorable characters, his novel structure is relatively loose. Surprisingly, four years later, Samuel in "Dickens dark joy," an article on earlier in the "structure of the novel," a book on Dickens evaluation has been corrected, he said. "Early in the novel Dickens improvisation and randomness of gradual change, he created relatively late rigorous structure, reflected in the various forms of prison attention.. "Samuel believes Dickens' Little Dorrit," "Tale of Two Cities", "Bleak House" other works directly to prison as the most important exhibition venues to Jian story, the idea careful. Samuel analysis of the place of the prison later researchers DA Miller, Jeremy. Tamblyn use Michel Foucault's theory to explain how Dickens was fascinated by the shape of the place had inspired prison role.

Character Feature. 1927 published "Aspects of the Novel" novel theory and practice to produce creative and full of universal significance of the role of being the twentieth century literary critics and bibles. The author of love. Mount Foster is renowned twentieth century novelist and critic, he not only in fiction industry reputation, but also because of the unique rare criticism known as the philosopher of the twentieth century. The book talked about novels of seven areas. the story, the characters, plot, fantasy, language, pattern and rhythm, deals with many well-known novelists. In the analysis of the character of the chapter, Forster Dickens to fictional example to discuss how the different types of characters and the reader's horizon of expectations resonance occurs. Foster will most of Dickens characters labeled "flat characters" label, this thesis research in the field of East-West Dickens has been widely recognized.

Foster The characters in the novel is divided into two types of flat characters and rounded characters. He thinks it's achievements in terms of shaping the character, flat characters may not be as huge round figure, but flat character is portrayed as a dramatic role when the round figure has incomparable advantages. Flat characters can also be called a "type of people" and "cartoon character." Flat character has two advantages. First, it is easy to identify, and second, the reader can easily remember them. Real flat characters can be summarized in one sentence. Foster believes Dickens characters in the novel are basically flat, but the shape of the flat Dickens characters in the reader's mind has left an indelible impression.

Foster believes any round of a complex novel requires both characters, but also need flat characters, among them hit each other in order to make work and life like. Those who do not like Dickens extremely adequate reason - he is a writer Chu foot. In fact he is one of the great writers we have. Brilliant achievements he has made in terms of shaping the type of person show. Content flat characters may contain strict than those Gou critics are willing to admit the more abundant. Foster seems, perhaps worse than Dickens Richardson, Defoe and Jane Austen on writing skills, but those vibrant Dickens novel, people read that led to abnormal vivid characters and those not vivid part. He used simple, exaggerated description, allowing readers to easily remember the character's appearance, to understand the character's personality traits, impressive. Synonymous with many of his characters but also because of its distinctive character traits and become certain characters are ordinary income English dictionary. 
Narrative Point of View. In discussing "the narrative point of view," Foster and "skill fiction" author Percy debate, Percy emphasize novel aesthetic theory, complex narrative methods attempt to boil down to some formula, and Foster believes that the narrative The strength lies in the ability of the individual to see if he can make his readers wrote novels believed everything. And Percy on the "Bleak House," the narrative techniques of affirmation contrary, he believes that "Bleak House" on the logic in terms of pieces, clueless, Dickens arbitrarily changed his narrative point of view, yet the reader coax have stumbled, so that we are convinced of the contents of his novels. Foster asked. why we do not quite picky reader, silk do not mind Dickens narrative confusion, still believe that the authenticity of this narrative Dickens, Forster believes the narrative point of view is important, but critics should not overemphasize its importance., it is far from an appropriate mix of important figures. In addition, the novelist wonderful flower pen, flatter readers believed is absolutely necessary.

Although Foster in "Aspects of the Novel," in view of the many causes varying degrees of controversy, but it has become too much emphasis on opposition to the art form and writing skills, creative activity oppose deny personalized called "top tips" theory pioneer. He opened a new chapter for the novel aesthetic theory, research Dickens also had a lasting impact. New Criticism has studied the founders TS Eliot Dickens novels. His commentary article in its contemporaries Dickens famous novelist Wilkie Collins were compared, and certainly the characterization Dickens novel.

Aldous Huxley is an important half of the twentieth century British novelist, his creative thinking deeply affected New Criticism, oppose Romantic literature advocating emotional self-expression that would not work as a manifestation of personality and OK hair emotional tools. In an evaluation of his Dickens' The Old Curiosity Shop, "the article on the creation of Dickens questioned believed in the creation of Dickens submerged in plenty of emotion among so disoriented. Huxley will be "The Old Curiosity Shop" and Dostoyevsky's "The Brothers Karamazov" by comparing with the former poor shape, like small children, child-resistant, which is named according to the shape of a child suffering Neuxar Many died after suffering a story. However, Huxley seems, according to the painful death of Neuxar touching death of a small child-resistant but vulgar naive. Huxley believed that the two effects are the result of such novelists different creative techniques. Dostoyevsky novels and attention to detail, he accurately observed everything on time Neuxar death occurred around the couch, the article is full of unparalleled wealth of factual details. Dickens and his eyes were blinded by passion Burgundy, for something a few days before his death in a small child resistant happening around her, he almost did not notice that the reader understands the suffering in addition to small children, as well as resistance to outside her virtues, nothing.Huxley thought Dickens made a taboo art. let emotion flooding. Huxley believed such an approach in the field of aesthetics should be condemned for.

\section{RESEARCH ON NEW CRITICISM OF DICKENS’ NOVELS}

Many members of the Bloomsbury group also Dickens literary creations of art criticism. Bloomsbury literary group known as the early twentieth century in the United Kingdom "unlimited inspiration, infinite passion, unlimited talent," a small group of intellectuals. Including John Galsworthy, love Virginia Woolf and the previously mentioned. Mount Foster, TS Eliot, including many gifted writers. This small group of self-contained with its aesthetic is unique in the then British towel just enormous impact. However, most members of the group and their creative skills to hold a mixed review Dickens attitude.

Woolf's stream of consciousness famous British novelist Charles Dickens novels for the development of the same criticism made important contributions. Not only is she the twentieth century, Britain's most distinguished writer, but also the most outstanding female critic. Woolf lifetime total of more than three hundred essays, book reviews and essays on the English novel to do a more comprehensive exposition. Like James, she is also a writer with the traditional fierce debate on their conservative, rigid and outdated way of creation made a fierce challenge. She thinks like a sort of realism Dickens the novelist's works created only a few characters and live appearances, but can not reveal the spiritual world and the psychological structure of characters. She recorded her to read 
"David Copperfield" feel in the "moment and other essays" in. For many people the Dickens and Shakespeare, Scott, Balzac par that Dickens was born as the first two, like the creation of the home, like the latter prolific, Woolf disagree, she thought Dickens once read this article, readers feel this must not be comparable with several writers. In Woolf seems Dickens lack of personal style, no understanding of the elite, do not understand the feelings of mature, such as Emile Lai elopement, Mrs. Steerforth despair, pain and other figures Beckham psychological describe neither true nor place.

However, with many literary Bloomsbury group members, Woolf Dickens is a love-hate. Although she did not appreciate Dickens' writing style and artistic skills, but she is still under the spell of his novels. Woolf believes this appeal is unable Dickens analysis and interpretation, this power is inherent. Woolf's complex attitude toward Dickens can be proved in many critics. Lillian' says in her article.. "I like Dickens, though I realize this is a very shameful thing children. "Woolf these words used to express the attitude of Dickerson probably not an exaggeration.

\section{References}

[1] Liu white .21 century domestic Dickens Review [J]. Hunan University of Science and Technology, 2011 (1).

[2] Xiangtan.innocence Dickens and China [M],Xiangtan University Press, 2008.

[3] Hong Shi Xue Romantic Realism - A Critical Biography of Charles Dickens [M] Beijing. Social Sciences Academic Press, 1996.

[4] Yin Enterprise level. New China 60 years of study and analysis of Dickens study [J]. Literature foreign, 2011 (4).

[5] Yin Enterprise level, Fen Gao, Tong Yanping criticism English fiction History [M] Shanghai. Shanghai Foreign Language Education Press, 2001.

[6] YuSanding. contemporary academic history research [C] Beijing. People's Publishing House, 2009. 